Proc. Estonian Acad. Sci. Geol., 2001, 50, 2, 75-85

\title{
TRACE FOSSILS DIDYMAULICHNUS \\ CF. TIRASENSIS AND MONOMORPHICHNUS ISP. FROM THE ESTONIAN LOWER CAMBRIAN, WITH A DISCUSSION ON THE EARLY CAMBRIAN ICHNOCOENOSES OF BALTICA
}

\author{
Sören JENSEN ${ }^{\mathrm{a}}$ and Kaisa MENS ${ }^{\mathrm{b}}$ \\ a Department of Earth Sciences, University of California, Riverside, CA 92521, USA; \\ soren@ucrac1.ucr.edu \\ b Institute of Geology, Tallinn Technical University, Estonia pst. 7, 10143 Tallinn, Estonia \\ Received 30 June 2000

\begin{abstract}
The bilobed trace fossil Didymaulichnus cf. tirasensis Palij in the Lower Cambrian Voosi Formation of western Estonia adds to the small number of pre-trilobite Cambrian trace fossils identified from Estonia. A possible earliest Cambrian Baltica trace fossil province, including trace fossils with an undulating bilobed and three-lobed lower surface, of which D. tirasensis is an example, is proposed. In Baltica traces of this type occur also in the Ukraine and northern Scandinavia. In each occurrence they are associated with vertical spiral traces and precede the local first appearance of arthropod-type trace fossils. The earliest Estonian arthropod-type trace fossil, Monomorphichnus isp., described here from the Sõru Formation, belongs to the trilobite-bearing Lower Cambrian.
\end{abstract}

Key words: ichnofossil, Didymaulichnus tirasensis, Monomorphichnus isp., Voosi Formation, Sõru Formation, Lower Cambrian, Estonia.

\section{INTRODUCTION}

Trace fossils are an important element of the Cambrian faunal record, particularly in siliciclastic sediments where body fossils generally are scarce. Early Cambrian trace fossils reflect the diversification of bilaterian animals, exhibiting a degree of morphological diversity, complexity and depth of infaunal habitation exceeding that of terminal Proterozoic (Vendian) trace fossils (e.g. Crimes 1987; Droser et al. 1999; Jensen et al. 2000). Relatively little has been published on trace fossils from the basal Cambrian of Estonia, which consists of the laterally equivalent siliciclastic Lontova Formation in the north 
and east, and the Voosi Formation in the west (Fig. 1). Treptichnus pedum, a complex three-dimensional burrow indicative of Cambrian (or younger) age, occurs in the basal Sämi Member of the Lontova Formation (Palij et al. 1983). The vertical spiral burrow Gyrolithes isp., generally considered to first appear in the Cambrian, occurs in the basal Taebla Member of the Voosi Formation (Jensen \& Mens 1999, fig. 3). A peculiar characteristic of argillaceous portions of the Lontova and Voosi formations is the preservation of traces as pyritic films

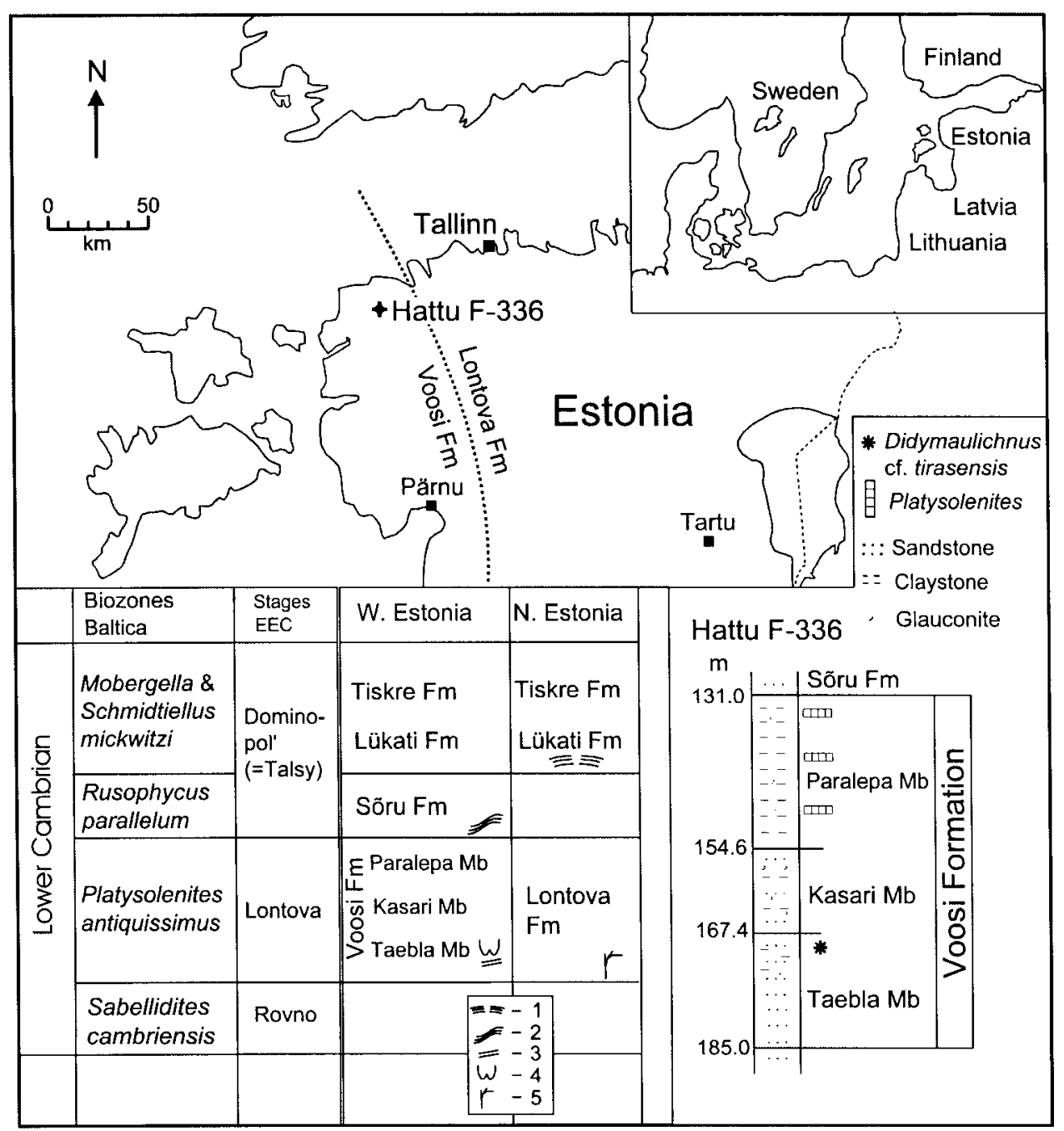

Fig. 1. Geographic location and stratigraphic context of trace fossils. Biozonation and correlation follows Mens et al. (1990). (Note that the Mobergella \& Schmidtiellus mickwitzi and Rusophycus parallelum zones in many schemes are united into the Schmidtiellus mickwitzi Zone). The lithological log of the Hattu F-336 core is based on observations of K. Mens. 1, Rusophycus; 2, Monomorphichnus; 3, Gyrolithes; 4, Didymaulichnus cf. tirasensis; 5, Treptichnus pedum. EEC East European Craton. 
that may occur in great abundance (e.g. Mens \& Pirrus 1977; Palij et al. 1983). This type of preservation largely yields simple horizontal forms assignable to Planolites and Helminthopsis. However, the identification of the pinnate branching trace fossil Dendrorhaphe isp. in the Lontova Formation of Latvia (Jensen \& Mens 1999) suggests that there is potential for recovery of a greater diversity and more complex trace fossils in the argillaceous sections, notably with the use of X-radiography. Ongoing examination also shows that many additional trace fossils are available in the sandier parts of the succession.

In this paper we present new information on trace fossils from the Voosi Formation in western Estonia. In connection with this we briefly discuss notable characteristics of the earliest Cambrian trace fossils on the East European Craton.

\section{GEOLOGICAL SETTING}

The so-called pre-trilobite Cambrian in Estonia is represented by siliciclastic sedimentary rocks of the Baltic Group, comprising the largely argillaceous Lontova Formation in the north and east, and the sandier Voosi Formation in the west (Fig. 1) (Mens et al. 1990; Mens \& Pirrus 1997a, 1997b). These strata contain the Lontova acritarch assemblage and a low-diversity small shelly fauna characteristic of the Platysolenites antiquissimus Zone (e.g. Mens \& Pirrus 1997a). The lower portion of the Voosi Formation consists mainly of fine-grained well-sorted sandstone of the Taebla Member containing rare glauconitic grains. Faunal remains include the organic-walled tube Sabellidites cambriensis and simple horizontal (Planolites) and vertical burrows (Mens \& Posti 1984), including the vertical spiral trace fossil Gyrolithes isp. (Jensen \& Mens 1999, fig. 3). From the glauconitic sandstone of the overlying Kasari Member, Mens \& Posti (1984) reported simple trace fossils and the agglutinated tubular fossils Platysolenites antiquissimus and Yanichevskyites petropolitanus. The heterolithic Paralepa Member, forming the terminal member of the Voosi Formation, yields Platysolenites antiquissimus, P. lontova, P. spiralis, and the helcionelloid mollusc Aldanella kunda (Mens \& Posti 1984; Mens \& Isakar 1999). Together with acritarchs (Mens \& Paškevičiene 1981), these fossils form the basis for biostratigraphy of the Voosi Formation.

The Taebla Member is assigned to the early part of the Lontova Stage and the Platysolenites antiquissimus Zone (Mens et al. 1990; Mens \& Pirrus 1997a). The position of this unit with respect to the Precambrian-Cambrian boundary is not exactly defined in Estonia due to the occurrence of a hiatus within the boundary interval (Mens \& Pirrus 1987). Cambrian-type trace fossils from the lower part of the Baltic Group in the Ukraine and other faunal remains suggest that the Precambrian-Cambrian boundary should be placed at the base (Mens et al. 1990), or perhaps within (Jensen \& Grant 1998), the Rovno Stage, which forms the basal unit of the Baltic Group. The Rovno deposits have not been recovered in Estonia (Fig. 1) but are distributed immediately beyond its eastern and southeastern boundary (Mens \& Pirrus 1997b). According to analyses of the relation of existing 
strata and hiatuses in the Vendian and Cambrian succession of the East Baltic, it can be concluded that the Rovno sedimentation embraces about a fourth of the whole Baltic time and conceivably lasted no more than 5-6 Ma.

\section{DIDYMAULICHNUS FROM THE VOOSI FORMATION}

A trace fossil from the lower part of the Voosi Formation is here identified as Didymaulichnus cf. tirasensis Palij, 1974. The trace is preserved in positive hyporelief and a counterpart negative epirelief in sandstone with silty parting from the Hattu F-336 drill core, western Estonia (Figs. 1,2). The hyporelief sandstone cast is partly covered by remains of adhering muddy siltstone. Due to the brittle nature of the slab, which shows incipient cracking, no preparation was attempted.
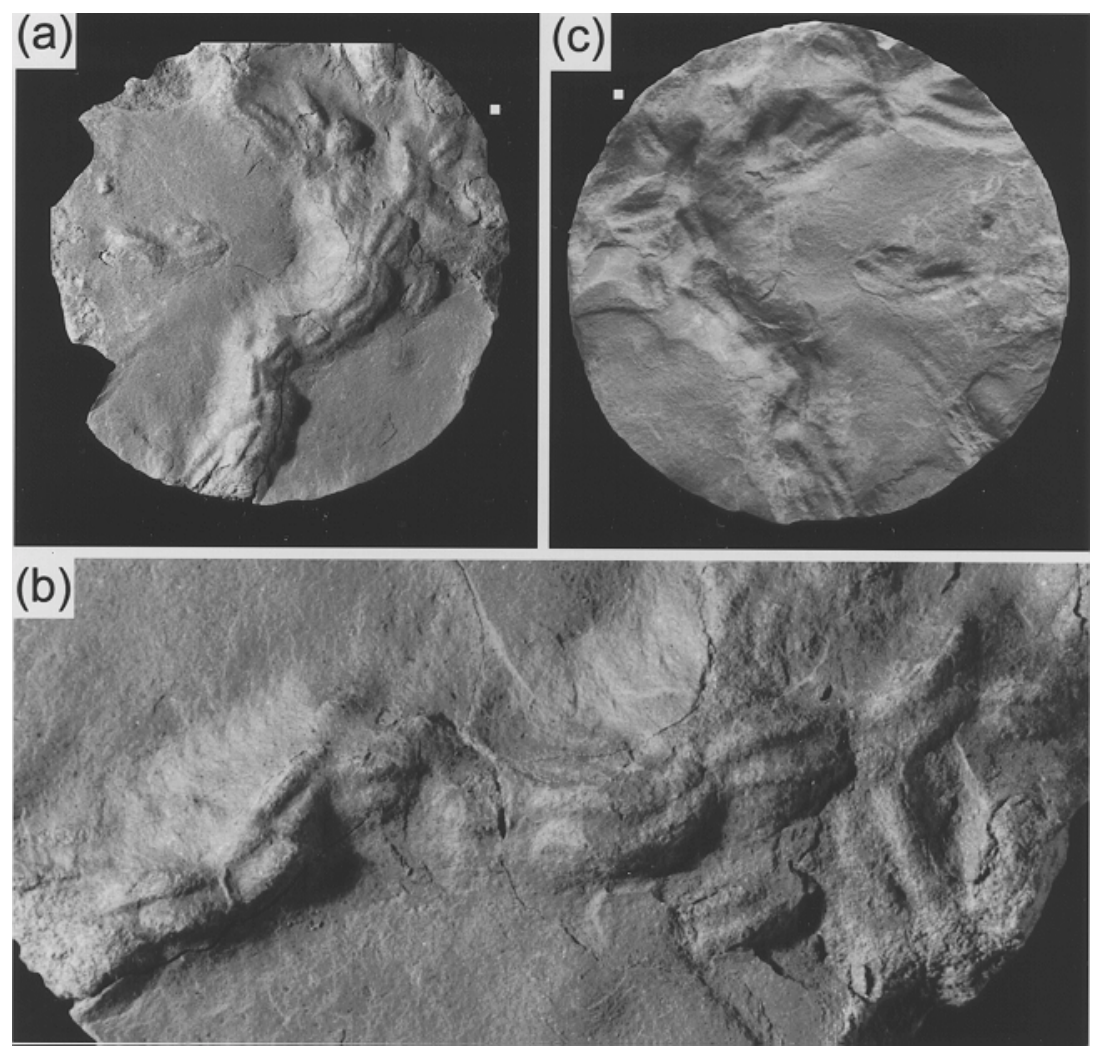

Fig. 2. Didymaulichnus cf. tirasensis from the Taebla Member, Voosi Formation, western Estonia. A bilobed trace fossil with strongly developed segmentation due to strong longitudinal curvature. Hattu F-336 drill core, 169 m. Institute of Geology, Tallinn Technical University, No. IG Va 1846. (a) Preserved in positive hyporelief, $\times 0.7$. (b) Close-up, $\times 1.9$. (c) Counterpart in negative epirelief, $\times 0.7$. 
The positive hyporelief consists of a series of bilobed, longitudinally arched, overlapping raised segments arranged in a straight to winding series (Fig. 2a,b). Each segment is $7-8 \mathrm{~mm}$ long and $5 \mathrm{~mm}$ wide at the base, has a deep, $2-3 \mathrm{~mm}$ wide median furrow that separates two narrow unornamented lobes (Fig. 2b). The burrow widens somewhat upwards. The two lobes are roughly parallel to each other but a weakly developed asymmetry is present in a few segments, the origin of which may be compactional (Figs. 2, 3). A few isolated bilobed segments also occur on the same slab (Figs. 2, 3).

The counterpart negative epirelief (Fig. 2c) largely mirrors the features of the hyporelief but also adds information by showing additional lobes not present on the hyporelief (e.g. upper right portion of Fig. 2c). Compared to the hyporelief there are segments of greater length and with less longitudinal curvature. Information from the hyporelief and epirelief has been combined in Fig. 3; it is not possible to tell whether the core area shows repeated crossing by a single animal or the activity of several individuals. Two oval depressions (Fig. 3) probably are either poorly preserved elements of $D$. cf. tirasensis or possibly two probes of an otherwise not preserved Treptichnus pedum.

This trace possesses distinctive features in common with Didymaulichnus tirasensis Palij, 1974, first described from the Khmelnitski Formation (upper part of the Rovno Stage) of the Ukraine (Palij 1974; Palij et al. 1983). Palij (1974, p. 502) described the segments in D. tirasensis as repeatedly deepening and shallowing and exhibiting overlap and imbrication. This is a significant characteristic that allies the Estonian specimen to D. tirasensis, as do the relatively narrow and deep lobes and the firmly incised median furrow (Palij 1974; Palij et al. 1983). Palij et al. (1983) describe the cross-section of D. tirasensis as trough-like to almost cylindrical, which also compares well with the Estonian material. The Estonian material differs in having a more strongly developed longitudinal curvature, a more distinct segmentation, and a wider median furrow. Additionally, our specimens are somewhat smaller than the Ukrainian material, which has widths of $8-14 \mathrm{~mm}$. Additional trace fossils from

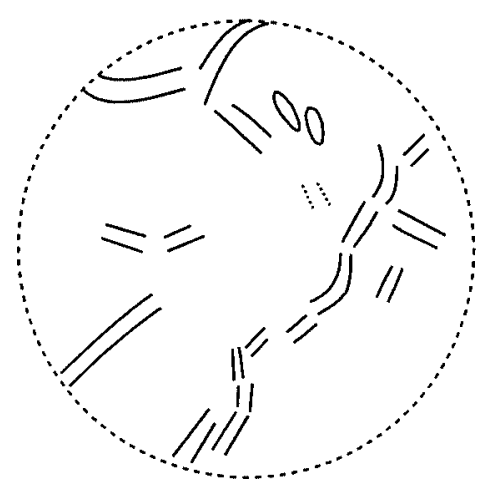

Fig. 3. Schematic tracings of the positions of the lobes combining information from the hyporelief and epirelief. The tracings are not intended to show the full extent of the lobes. 
the Khmelnitski Formation, described as "trails of bilobate to three-lobed structure", show general similarity with the Estonian material but in addition have occasional three-lobed development (Palij et al. 1983, p. 88, pl. 52, fig. 3). The overall characteristics of this trace are otherwise identical to those of $D$. tirasensis (cf. Palij et al. 1983, pl. 52, figs. 1, 3) and probably are part of intergradational morphological variation. Since our understanding of the type material of Didymaulichnus tirasensis is based solely on the literature and in recognition of the differences outlined above, we assign the specimen from the Voosi Formation to Didymaulichnus cf. tirasensis.

There are few reports of D. tirasensis outside the Ukraine. Fedonkin (1990) reported $D$. cf. tirasensis from the Kessyuse Formation, northern Siberia, apparently at a level belonging to the lower portion of the Nemakit Daldynian Stage of debated age close to that of the Precambrian-Cambrian boundary. The illustrated material does not show any imbrication and overlap of curved segments and arguably this material may be more properly assigned to Didymaulichnus lyelli (see below). Indeed, the relation of Didymaulichnus tirasensis to other ichnospecies of Didymaulichnus seems somewhat confused. According to Palij (1974, p. 503), D. tirasensis differs from D. miettensis, a form apparently restricted to the Lower Cambrian, in the absence of lateral bevels, a smaller size, and also that the trace only rarely stays within the same horizontal plane. The type species of Didymaulichnus, D. lyelli (Rouault, 1850) is a bilobed trace with no lateral bevels and with no, or relatively minor, longitudinal undulations. Greater similarity to D. tirasensis is found in Didymaulichnus alternatus Pickerill, Romano \& Meléndez, 1984, from the Lower Ordovician of Spain. This form has alternate deep and less deep sections. Pickerill et al. (1984) distinguished this species from $D$. tirasensis by the presence of lateral bevels in the latter (as discussed above, this is not correct) and the smaller size of the Spanish material (7-9 mm wide), which, however, overlaps the lower range of the type material of $D$. tirasensis. There are several interesting similarities between $D$. tirasensis and $D$. alternatus, the varying multilobate development in deep specimens, and aligned "rusophycid-like" impressions (Pickerill et al. 1984, p. 261). A possible difference is that the lobes in D. alternatus are more rounded and that the median furrow is less wide and not wedge-shaped; however, the relationship of these ichnospecies may warrant further consideration.

\section{DISCUSSION}

The Baltic Group forms a relatively homogeneous package of siliciclastic sediments with a similar development over a wide area. Its base reflects the onset of widespread marine deposition and the top reflects a relative fall in sea level (Mens et al. 1990). Trace fossils from the Baltic Group were summarized in Palij et al. (1983). The most diverse record comes from the Podolia area of the Ukraine (Palij et al. 1983; Gureev et al. 1985; Gureev 1986). Thus, the Khmelnitski 
Formation yields forms such as Treptichnus triplex, Bergaueria major, Didymaulichnus tirasensis, and Gyrolithes polonicus. As mentioned above, the Khmelnitski Formation has both bilobed and three-lobed traces with a similar undulating development (Palij et al. 1983, pl. 52, figs. 1, 6) and with intermediate forms (Palij et al. 1983, pl. 52, fig. 3), suggesting that these were produced by the same type of animal. Traces with a three-lobed lower surface are found also with segments developed in a zigzag pattern (Treptichnus triplex). A comparable trace fossil assemblage occurs in the Lublin slope of Poland notably with the occurrence of Treptichnus triplex (Pacześna 1996). Trace fossils with a threelobed lower surface occur also in northern Scandinavia (Jensen \& Grant 1998), suggesting a wide distribution of this type of trace on the earliest Cambrian Baltica. The vertical spiral Gyrolithes isp. occurs both in Poland and northern Scandinavia (Pacześna 1996; Jensen \& Grant 1998). Trace fossils, as a rule, are of limited use in palaeogeographic studies since morphologic convergence is rampant. Certain invertebrate trace fossils that show distinctive features of their producer may, however, have restricted palaeogeographic distributions. Astropolichnus hispanicus, a plug-shaped vertical burrow with a broad upper rim with radial ridges, has been widely found in a restricted area of the Cambrian Gondwana (Pillola et al. 1994). As a further example the distinct patterns registered in limb imprints of trilobite can be used to address palaeogeographic problems (e.g. Seilacher \& Crimes 1969). Also, assemblages of trace fossils may be suggestive of palaeogeographic provinciality, though considerable caution is required in analysing the cause of this pattern. For example, Orr (1996) noted similarities of early Ordovician ichnofaunal assemblages from various deposits that on palaeogeographic maps were positioned at high southerly palaeolatitudes.

By the end of the Vendian, Baltica had rifted from a terminal Proterozoic supercontinent, and throughout the Cambrian Baltica formed an independent plate. Signs of endemism are found in olenellid trilobites which define a late Early Cambrian Baltic Faunal Province (e.g. Ahlberg et al. 1986). Although none of the trace fossils in the Baltic Group (and correlatives) show morphologic "fingerprinting" of the distinctiveness of some Rusophycus or Cruziana, there are, as discussed above, some notable features. Traces with an undulating threeor bilobed lower surface are not restricted to the earliest Cambrian in Baltica, but the common occurrence of this type of relatively large trace together with vertical spiral trace fossils is notable. An interesting ichnological feature of the Baltic Group is the lack of traditional arthropod-type trace fossils. In sections worldwide, arthropod-type trace fossils, such as Rusophycus, generally appear significantly down-section of the first trilobite body fossils. In particular Monomorphichnus, sets of occasionally laterally repeated ridges occur close to the Precambrian-Cambrian boundary in many sections (Crimes 1987), though care is needed to distinguish these from similar-looking inorganic tool marks. In the Precambrian-Cambrian boundary GSSP in Newfoundland, Monomorphichnus first appears $2.5 \mathrm{~m}$ above the base of the Treptichnus pedum Zone (Narbonne et al. 1987), and Monomorphichnus is used along with 
Treptichnus pedum in defining the base of the Spanish basal Cambrian Cordubian Stage (Liñan et al. 1993). Arthropod-type trace fossils have not been reported from the Baltic Group in the Ukraine and are probably lacking also in Baltic Group equivalents in northern Sweden (Jensen \& Grant 1998). There is reference to a possible occurrence of Rusophycus in the Mazowsze Formation, in the Lublin area of Poland, at a level correlated with the Lontova Stage (Fedonkin 1977). Simple Rusophycus from northern Norway (Banks 1973) may be of comparable age, but additional biostratigraphic constraint is needed for this occurrence. In Estonia, trilobites appear in the Lükati Formation, which also yields diverse arthropod-type trace fossils (Mens \& Pirrus 1977). Here we report the occurrence of Monomorphichnus isp., in finely laminated sandstone close to the base of the Sõru Formation (Fig. 4). The Sõru Formation is subjacent to the Lükati Formation but may not precede the first regional appearance of trilobites since it has been correlated with the Hardeberga Sandstone in southern Sweden, which yields possible trilobite impressions (Ahlberg et al. 1986; Mens et al. 1990). The apparently simultaneous appearance of trilobite body fossils and arthropod-type trace fossils on Baltica (with the above possible exceptions needing further study) is unexpected and cannot be explained by lack of suitable facies for preservation of this type of trace fossils in the Baltic Group.

Another noteworthy feature of the pre-trilobite Cambrian on Baltica is the occurrence of problematic discoidal fossils. Gureev $(1987,1988)$ and Gureev et al. (1985) reported several discoidal fossils from the Baltic Group in the Ukraine, including Kullingia concentrica, Elasenia cf. aseeva, Ternavellus vialovi, and Pollukia shulgae. Kullingia concentrica occurs in strata of comparable age of the Torneträsk Formation in northern Sweden (Føyn \& Glaessner 1979; Jensen \& Grant 1998). Discoidal fossils have recently been reported also from the earliest Cambrian of northern Norway, identified as Nimbia occlusa and Tirasiana sp. (Crimes \& McIlroy 1999). Interpretation and taxonomy of such comparatively simple forms is notoriously problematic, but these reports add a Vendian flavour to these earliest Cambrian sediments, in agreement with recent finds of frond-like

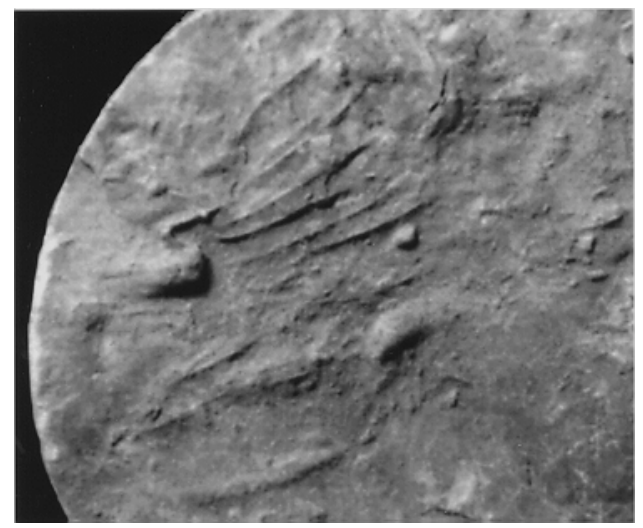

Fig. 4. Monomorphichnus isp. in finely laminated sandstone close to the base of the Sõru Formation in the Kasari-16 drill core, $315.8 \mathrm{~m}, \times 1$. Institute of Geology, Tallinn Technical University, No. IG Va 1847. 
Ediacara-type fossils in the earliest Cambrian of Australia (Jensen et al. 1998) and close to the Precambrian-Cambrian boundary in Namibia (Narbonne et al. 1997).

\section{ACKNOWLEDGEMENTS}

We thank N. C. Hughes, Riverside, for critical remarks and linguistic improvement of an earlier version of the manuscript. The study of Estonian Cambrian palaeontological collections was supported by grant No. 3237 of the Estonian Science Foundation. A major part of the work on this manuscript was carried out when SJ was at the Department of Earth Sciences, University of Cambridge. Funding, initially from the Leverhulm Trust, and subsequently NERC (grant GR3/10713 to Simon Conway Morris) is gratefully acknowledged.

\section{REFERENCES}

Ahlberg, P., Bergström, J. \& Johansson, J. 1986. Lower Cambrian olenellid trilobites from the Baltic Faunal Province. Geol. Förenin. Stockholm Förh., 108, 39-57.

Banks, N. L. 1973. Trace fossils in the Halkkavarre section of the Dividal Group (?late Precambrian-Lower Cambrian), Finnmark. Norges Geol. Unders., 288, 1-6.

Crimes, T. P. 1987. Trace fossils and correlation of late Precambrian and early Cambrian strata. Geol. Mag., 124, 97-119.

Crimes, T. P. \& McIlroy, D. 1999. A biota of Ediacaran aspect from lower Cambrian strata on the Digermul Peninsula, arctic Norway. Geol. Mag., 136, 633-642.

Droser, M. L., Gehling, J. G. \& Jensen, S. 1999. When the worm turned: concordance of Early Cambrian ichnofabric and trace-fossil record in siliciclastic rocks of South Australia. Geology, 27, 625-628.

Fedonkin, M. A. 1977. Precambrian-Cambrian ichnocoenoses of the East European Platform. In Trace Fossils 2 (Crimes, T. P. \& Harper, J. C., eds.). Geol. J. Spec. Issue, 9, 183-194.

Fedonkin, M. A. 1990. Paleoichnology of Vendian Metazoa. In The Vendian System, Vol. 1: Paleontology (Sokolov, B. S. \& Ivanovsky, A. B., eds.), pp. 132-137. Springer-Verlag, Berlin.

Føyn, S. \& Glaessner, M. F. 1979. Platysolenites, other animal fossils, and the PrecambrianCambrian transition in Norway. Nor. Geol. Tidsskr., 59, 25-46.

Gureev, Yu. A. 1986. On the perspectives of paleoichnological methods in stratigraphy. Tektonika Stratig., 27, 42-47 (in Russian).

Gureev, Yu. A. 1987. Morphological analysis and systematics of Vendiata. In-t geol. nauk, Akad. nauk Ukrainskoj SSR. Preprint 87-15.

Gureev, Yu. A. 1988. Non-skeletal Vendian fauna. In Biostratigrafiya i paleogeograficheskie rekonstruktsii dokembriya Ukrainy (Ryabenko, V. A., ed.), pp. 65-81. Naukova Dumka, Kiev (in Russian).

Gureev, Yu. A., Velikanov, V. A. \& Ivanchenko, V. Ya. 1985. Non-skeletal fauna from the deposits of the Baltic and Berezhkovsky series of Podolia. Dokl. AN URSR, Ser. B, 6, 10-13 (in Russian).

Jensen, S. \& Grant, S. W. F. 1998. Trace fossils from the Dividalen Group, northern Sweden: implications for Early Cambrian biostratigraphy of Baltica. Nor. Geol. Tidsskr., 78, 305317. 
Jensen, S. \& Mens, K. 1999. A Lower Cambrian shallow-water occurrence of the branching "deep-water" type trace fossil Dendrorhaphe from the Lontova Formation, eastern Latvia. Paläontol. Z., 73, 187-193.

Jensen, S., Gehling, J. G. \& Droser, M. L. 1998. Ediacara-type fossils in Cambrian sediments. Nature, 393, 567-569.

Jensen, S., Saylor, B. Z., Gehling, J. G. \& Germs, G. J. B. 2000. Complex trace fossils from the terminal Proterozoic of Namibia. Geology, 28, 143-146.

Liñan, E., Perejón, A. \& Sdzuy, K. 1993. The Lower-Middle Cambrian stages and stratotypes from the Iberian Peninsula. Geol. Mag., 130, 817-833.

Mens, K. \& Isakar, M. 1999. Facies distribution of Early Cambrian molluscs in Estonia. Proc. Estonian Acad. Sci. Geol, 48, 110-115.

Mens, K. \& Paškevičiene, L. 1981. Environmental control in the distribution of acritarchs in the Lontova Stage of Estonia. ENSV TA Toim. Geol., 30, 148-155 (in Russian).

Mens, K. \& Pirrus, E. 1977. Stratotypes of the Cambrian Formations of Estonia. Valgus, Tallinn (in Russian).

Mens, K. \& Pirrus, E. 1987. Hiatuses in the East Baltic Vendian and Cambrian sections. Proc. Acad. Sci. ESSR. Geol., 36, 49-57 (in Russian).

Mens, K. \& Pirrus, E. 1997a. Cambrian. In Geology and Mineral Resources of Estonia (Raukas, A. \& Teedumäe, A., eds.), pp. 39-51. Estonian Acad. Publ., Tallinn.

Mens, K. \& Pirrus, E. 1997b. Vendian-Tremadoc clastogenic sedimentation basins. In Geology and Mineral Resources of Estonia (Raukas, A. \& Teedumäe, A., eds.), pp. 184-191. Estonian Acad. Publ., Tallinn.

Mens, K. \& Posti, E. 1984. Distribution and correlation significance of organic remains in the Baltic Series of Estonia. In Stratigrafiya drevnepaleozoiskikh otlozhenij Pribaltiki (Männil, R. \& Mens, K., eds.), pp. 5-17. Inst. geol. Akad. nauk ÉSSR, Tallinn (in Russian).

Mens, K., Bergström, J. \& Lendzion, K. 1990. The Cambrian System on the East European Platform. IUGS Publ., 25.

Narbonne, G. M., Myrow, P. M., Landing, E. \& Anderson, M. M. 1987. A candidate stratotype for the Precambrian-Cambrian boundary, Fortune Head, Burin Peninsula, southeastern Newfoundland. Can. J. Earth Sci., 24, 1277-1293.

Narbonne, G. M., Saylor, B. Z. \& Grotzinger, J. P. 1997. The youngest Ediacaran fossils from southern Africa. J. Paleont., 71, 953-967.

Orr, P. J. 1996. The ichnofauna of the Skiddaw Group (early Ordovician) of the Lake District, England. Geol. Mag., 133, 193-216.

Pacześna, J. 1996. The Vendian and Cambrian ichnocoenoses from the Polish part of the EastEuropean Platform. Pr. Państw. Inst. Geol., 152, 1-77.

Palij, V. M. 1974. Bilobite traces from the deposits of the Baltic series in the Dniestr region. Dokl. AN URSR, Ser. B, 1, 499-503.

Palij, V. M., Posti, E. \& Fedonkin, M. A. 1983. Soft-bodied Metazoa and animal trace fossils in the Vendian and early Cambrian. In Upper Precambrian and Cambrian Palaeontology of the East-European Platform (Urbanek, A. \& Rozanov, A. Y., eds.), pp. 56-94. Publ. House Wydawnictwa, Warszawa.

Pickerill, R. K., Romano, M. \& Meléndez, B. 1984. Arenig trace fossils from the Salamanca area, western Spain. Geol. J., 19, 249-269.

Pillola, G. L., Leone, F., Gámez-Vintaned, J. A., Liñan, E., Dabard, P. \& Chauvel, J. J. 1994. The Lower Cambrian ichnospecies Astropolichnus hispanicus: palaeoenvironmental and palaeogeographic significance. In Studies on Ecology and Paleoecology of Benthic Communities (Matteucci, R. et al., eds.). Spec.Vol. Boll. Soc. Paleont. Ital., 2, 253-267.

Seilacher, A. \& Crimes, T. P. 1969. "European" species of trilobite burrows in Eastern Newfoundland. In North Atlantic - Geology and Continental Drift (Kay, M., ed.). Mem. Am. Ass. Petrol. Geol., 12, 145-148. 


\title{
IHNIIDID DIDYMAULICHNUS CF. TIRASENSIS JA MONOMORPHICHNUS ISP. EESTI ALAMKAMBRIUMIS JA BALTIKA ÜRGMANDRI VARAKAMBRIUMI VÕIMALIK IHNOKOOSLUS
}

\author{
Sören JENSEN ja Kaisa MENS
}

\begin{abstract}
On kirjeldatud lainja bilobaarse (kahesagaralise) ihnofossiili Didymaulichnus cf. tirasensis Palij leidu Voosi kihistu Taebla kihistikust Lääne-Eesti Hattu F-336 läbilõikes. Nii bilobaarseid kui ka trilobaarseid ihnofossiile on leitud mitmest pretrilobiitse varakambriumi läbilõikest Ida-Euroopa platvormil ja need on üsna iseloomulikud selle ea kihtidele. Pretrilobiitse varakambriumi vanemates kihtides kaasnevad neile hilisvendile omased diskoidsed (kettakujulised) ihniidid. Baltika ürgmandri selle ajalõigu setendites aga peaaegu puuduvad artropoodi tüüpi organismide elutegevusjäljed. Esimene seda tüüpi organism - Monomorphichnus isp. - on leitud alles Sõru kihistust, mis on vanim trilobiitse varakambriumi stratigraafiline üksus Eestis.

Märgitud tunnusjooned lubavad Baltika ürgmandrit varakambriumi pretrilobiitsel eal vaadelda iseseisva ihnoprovintsina.
\end{abstract}

\section{ИХНОФОССИЛИИ DIDYMAULICHNUS CF. TIRASENSIS И MONOMORPHICHNUS ISP. ИЗ НИЖНЕГО КЕМБРИЯ ЭСТОНИИ, А ТАКЖЕ КОММЕНТАРИЙ К РАННЕКЕМБРИЙСКОМУ ИХНОЦЕНОЗУ БАЛТИКИ}

\section{Сёрен ЙЕНСЕН и Кайса МЕНС}

Приведено описание волнистого двухлопастного ископаемого следа Didymaulichnus cf. tirasensis Palij из таэблаской пачки воозиской свиты разреза Хатту F-336 Западной Эстонии. Вместе с двух- и трехлопастными ихнитами, обнаруженными в дотрилобитовом нижнем кембрии, сравнительно часто, особенно в самых нижних слоях этого стратиграфического уровня, встречаются дисковидные окаменелости. Однако в составе этого ихноценоза отсутствуют достоверно доказанные следы жизнедеятельности трилобитоподобных организмов. Высказано предположение о существовании самостоятельной ихнопровинции на плите древней Балтики в дотрилобитовое раннекембрийское время. 